\title{
Trial to increase the sensitivity of Brucella antigens treated with Binary ethylene imine as inactivated agent
}

\author{
Hussein K. Eldeen *and Salwa S. Awad \\ Veterinary Serum and Vaccine Research Institute, Abbassia, Cairo, Egypt.
}

\begin{abstract}
The diagnosis of brucellosis is mainly based on the detection of anti-LPS antibodies. High temperature kills Brucella cells by causing lysis of the membrane, so the phenol-heat killed brucella antigen may lake specificity as a result of destruction the majority of proteins in the cell wall. Accordingly, attention was directed to produce antigen using binary ethylene imine as an inactivator. The produced antigen showed high specificity in detecting Brucella abortus and Brucella melitensis-infected animals, but sensitivity was not affected in comparison with the standard Rose Bengal antigen. In Enzyme immunotransfer blot (EITB), phenol-heat killed brucella cells showed only 3 bands $(37.375,23.47$ and $7.83 \mathrm{kDa})$ that denotes denaturation for at least 6 bands whereas binary inactivated brucella cells showed similarity with non-treated ones.
\end{abstract}

Brucellosis is an important infectious disease that mainly affects cattle, sheep and goats. The disease in cattle is most commonly caused by Brucella abortus whilst brucellosis in sheep and goats, is caused by Brucella melitensis, a very important zoonotic agent (Joint, 1986; Sangari et al., 1996; Garin-Bastuji et al., 1998; MoriyÓn and Gamazo, 1998; Schurig et al., 2002).

Isolation of brucella organisms from the suspected animal is the diagnostic method known to produce the best results in terms of specificity. However, this method has a limited sensitivity, expensive and cumbersome and has the added difficulty of being unpractical to apply at a large scale in control campaigns. Accordingly, the indirect diagnosis of disease based on serological tests is of choice in the eradication programmes. The standard Rose Bengal (RB) and complement fixation (CFT) tests are the main serological tests used to detect antibodies against Brucella abortus and Brucella melitensis infections. Both tests have been used for several decades, proving to be successful for eradicating bovine brucellosis in some countries, and are the official tests currently used in the European rules for the eradication of $B$. melitensis infection in small ruminants. Nevertheless, there is evidence that both tests are significantly less effective for the diagnosis of

* Corresponding author. Tel.: +20 223901930

E-mail address: kamalkhalil1@yahoo.com (H.K.Eldeen). brucellosis in sheep and goats than in cattle. (Joint, 1986; Garin-Bastuji et al.,1998; Nielsen 2002).

The EU rules consider that the best strategy for diagnosing sheep and goat brucellosis is the combined use of Rose Bengal as the screening test and the complement fixation (CF) test as the confirmatory test. However, it has been reported that a relatively high proportion of sheep and goats from B. melitensis infected flocks showed negative results in the standard Rose Bengal test but positive in the $\mathrm{CF}$ test, questioning the sensitivity of the former as a screening test (Blasco et al.,1994). Thus, the simultaneous use of both is recommended to obtain a maximal sensitivity (Garin-Bastuji et al., 1998). Therefore, the aim of this work was based upon, trying to increase the sensitivity of Rose Bengal by using binary ethylene imine as an inactivator, comparing between standard Rose Bengal (SRB) and Binary Rose Bengal (BRB) by Enzyme linked immunotransfer blot (EITB).

\section{Material and methods}

Brucella strains. Virulent Brucella abortus strain 2308 (S-2308) was obtained from Vet. Lab., New How, Surry, K.T.15 England. This strain was used for experimental infection of guinea pigs. Virulent Brucella melitensis strain $16 \mathrm{M}$ was obtained from Vet. Lab., New How, Surry, K.T.15 England. This strain was used for experimental infection of guinea pigs.

Animals and Experimental design. One hundred and fifty guinea pigs (300-350 grams body weight) were divided into 3 equal groups, the first was injected with virulent Brucella 
Fig (1):Inactivation curve of Brucella living cells (S99) with different concentrations of BEI $0.02 \mathrm{M}, 0.03 \mathrm{M}$ and $0.04 \mathrm{M}$

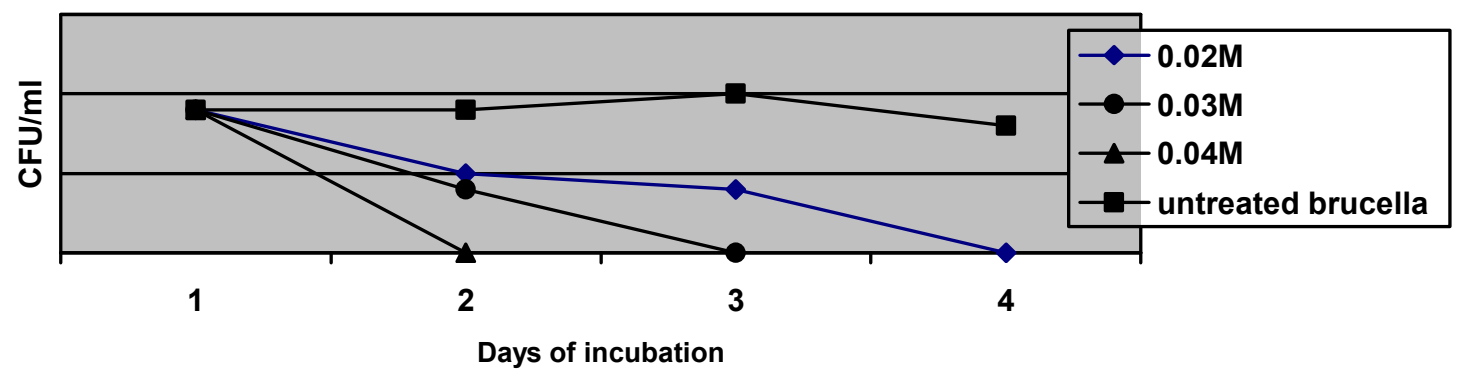

abortus strain 2308 (S-2308) $\left(5 \times 10^{3}\right.$ viable count), the $2^{\text {nd }}$ group was injected with virulent Brucella melitensis strain $16 \mathrm{M}\left(5 \times 10^{3}\right.$ viable count) and the $3^{\text {rd }}$ was control non-infected.

Serum samples. Sera were collected after inoculation of 2 groups of guinea pigs with virulent Brucella abortus strain 2308 and Brucella melitensis strain $16 \mathrm{M}$. All animals were tested for brucella antibodies weekly for 3 months post infection. All sera were tested against the antigens using standard Rose Bengal and binary Rose Bengal. Sera from control noninfected guinea pigs were also collected.

Binary ethylene amine (BEI) preparation. It was prepared through cyclization of $1 \mathrm{M} 2$ bromoethylamine hydrobromide in previously wormed $0.2 \mathrm{~N}$ sodium hydroxide in water bath $37^{\circ} \mathrm{C}$, till $\mathrm{pH}$ falls to 7.2 . The solution was immediately used as inactivating agent (Girard and Mary, 1990).

\section{Antigens preparation.}

i. Whole cell antigen preparation. B. abortus biovar 1 (S 99) was cultivated onto potato agar. The bacteria were harvested in phenol saline from their respective growth media and heat killed for $2 \mathrm{~h}$ at $95^{\circ} \mathrm{C}$. Rose Bengal antigen was prepared according to (Alton, et al.,1988)

ii. Binary ethylene amine Rose Bengal antigen. Brucella cells (S 99) were collected in sterile saline and the viable count was adjusted to 9X10 9 CFU in three aliquots. BEI was added with different concentrations in each vial $(0.02$ $\mathrm{M}, 0.03 \mathrm{M}$ and $0.04 \mathrm{M}$ ). The three vials were incubated at $37{ }^{\circ} \mathrm{C}$, and the viable count was determined periodically. (Hassanien, 1992).

Preparation of Hyperimmune serum using Brucella abortus S (99). Ten guinea pigs (300350 g. body weight each) were injected intraperitoneally with $1 \mathrm{ml}$ of a suspension containing $10^{9}$ organisms $/ \mathrm{ml}$ of heat killed, phenol preserved B. abortus $\mathrm{S}$ (99) in PBS in days $0,7,21,28$. After 21 days, guinea pigs were boostered for two times by 3 weekly intraperitonial injections of $10^{9}$ heat killed $B$. abortus cells. (Shohreh Farshad, et al., 2002)

Enzyme immunotransfer blot (EITB). Different Brucella antigens (10ug each) were electrophoresed using 10\% SDS-PAGE under reducing conditions (Lammli, 1970).The fractionated antigen was electrically transferred onto nitrocellulose (NC) membrane. NC sheets were blocked by $5 \%$ BSA in PBS for $2 \mathrm{~h}$. on a rocker platform. Hyperimmune sera prepared in guinea pigs were diluted at 1:100 in BSA/ PBS$\mathrm{T}$ incubated with the fractionated Brucella NC strips for $2 \mathrm{~h}$. on a rocker platform. Following washing, protein-A-peroxidase (as conjugate) diluted at 1:1000 (Sigma Co.) in PBS-T was added to NC strips for $1 \mathrm{~h}$. on a rocker platform. The chromogen 3- amino, 9-ethyl cabazole (AEC) substrate (Sigma) was added to NC strips and allowed to develop for $30 \mathrm{~min}$. The reaction was visualized by the naked eye.

\section{Results and Discussion}

The world Health organisation (WHO) laboratory biosafety manual classifies Brucella in Risk group III, as brucellosis is readily transmissible to humans causing acute febrile illness - undulant fever - which may progress to a more chronic form and can also produce serious complications affecting the musculoskeletal, cardiovascular, and central nervous systems. Infection is often due to occupational exposure and is essentially acquired by the oral, respiratory, or conjunctival routes, but ingestion of dairy products constitutes the main risk to the general public. There is an occupational risk to veterinarians and farmers who handle infected animals and aborted fetuses or placentae (WHO, 1997; European Commission, 1999).

The diagnosis of brucellosis is mainly based on the detection of anti-LPS antibodies. Due to substantial similarity of the O-polysaccharide of brucella LPS to that of various other Gram- 
Table (1): Comparison between standard and Binary inactivated Rose Bengal in detection of experimentally infected guinea pigs' sera.

\begin{tabular}{|c|c|c|c|c|c|}
\hline \multirow[t]{2}{*}{ Group } & \multirow{2}{*}{$\begin{array}{c}\text { Guinea } \\
\text { pigs } \\
\text { number }\end{array}$} & \multicolumn{2}{|c|}{ Standard Rose Bengal } & \multicolumn{2}{|c|}{$\begin{array}{c}\text { Binary Rose Bengal } \\
(0.02 M)\end{array}$} \\
\hline & & + ve & -ve & $+\mathbf{v e}$ & -ve \\
\hline $\begin{array}{l}\text { I- experimentally } \\
\text { Infected guinea pigs with Brucella } \\
\text { abortus } 2308\end{array}$ & 50 & 50 & 0 & 50 & 0 \\
\hline $\begin{array}{l}\text { II-experimentally infected guinea } \\
\text { pigs with Brucella melitensis M } 16\end{array}$ & 50 & 45 & 5 & 48 & 2 \\
\hline III-non-infected guinea pigs & 50 & 1 & 49 & 0 & 50 \\
\hline
\end{tabular}

Table (2): Whole cell protein analysis of different Brucella antigens using Enzyme immunotransfer blot.

\begin{tabular}{|c|c|c|c|c|c|c|}
\hline Lanes: & Marker & Lane 1 & Lane 2 & Lane 3 & Lane 4 & Lane 5 \\
\hline Rows & (mol.w.) & (mol.w.) & (mol.w.) & (mol.w.) & (mol.w.) & (mol.w.) \\
\hline r 1 & 175 & & & & & \\
\hline r 2 & & 128.355 & 128.355 & & & \\
\hline r 3 & 83 & & & & & \\
\hline r 4 & 62 & 60.286 & 60.286 & & 60.286 & \\
\hline r 5 & & 54.577 & & 54.577 & 54.577 & \\
\hline r 6 & & & 52.679 & 52.679 & & \\
\hline r 7 & 47.5 & 49.959 & 49.959 & 49.959 & 49.959 & \\
\hline r 8 & & & & 44.594 & 44.594 & \\
\hline r 9 & & 41.313 & 41.313 & & & \\
\hline r 10 & & & & 37.375 & 37.375 & 37.375 \\
\hline r 11 & 32.5 & 32.160 & & 32.160 & 32.160 & \\
\hline r 12 & & & 30.825 & 30.825 & 30.825 & \\
\hline r 13 & & & & 28.641 & 28.641 & \\
\hline r 14 & & 26.748 & 26.748 & 26.748 & 26.748 & \\
\hline r 15 & 25 & & & & & $23 . .47$ \\
\hline r 16 & 16.5 & & 17.775 & & 17.775 & \\
\hline r 17 & & 13.723 & & 13.723 & 13.723 & \\
\hline r 18 & & & 10.38 & 10.38 & & \\
\hline r 19 & & 7.83 & & & & 7.83 \\
\hline
\end{tabular}

Lane (1): untreated Brucella, Lane (2): Brucella treated with 0.02M of BEI, Lane (3): Brucella treated with $0.03 \mathrm{M}$ of BEI, Lane (4): Brucella treated with 0.04M of BEI, Lane (5): Heat killed Brucella.

negative bacteria, serological tests of samples containing high amounts of LPS lack specificity. Hence, the development of assays based on more specific protein antigens is an essential subject in brucellosis research. The aim of this study was proteomic characterization of various antigen preparations from the diagnostic reference strain; Brucella abortus (S99) and the identification of immunogenic proteins suitable for serological assays (Nöckler, et al., 2006).

The Brucella cell envelope is a three-layered structure in which an inner or cytoplasmic membrane, a periplasmic space, and an outer membrane can be differentiated. Brucella cell walls consist of a peptidoglycan (PG) layer strongly associated with the outer membrane. The outer membrane contains LPS, proteins and phospholipids. A lipoprotein covalently linked to PG has been described as a major OMP (Farshad et al., 2002).

The procedures most frequently used for the sero diagnosis of brucellosis are the rapid slide 
Fig (2): Enzyme immunotransfer blot of different Brucella antigens against crude hyperimmune serum prepared in guinea pigs (Brucella S99 antiserum).

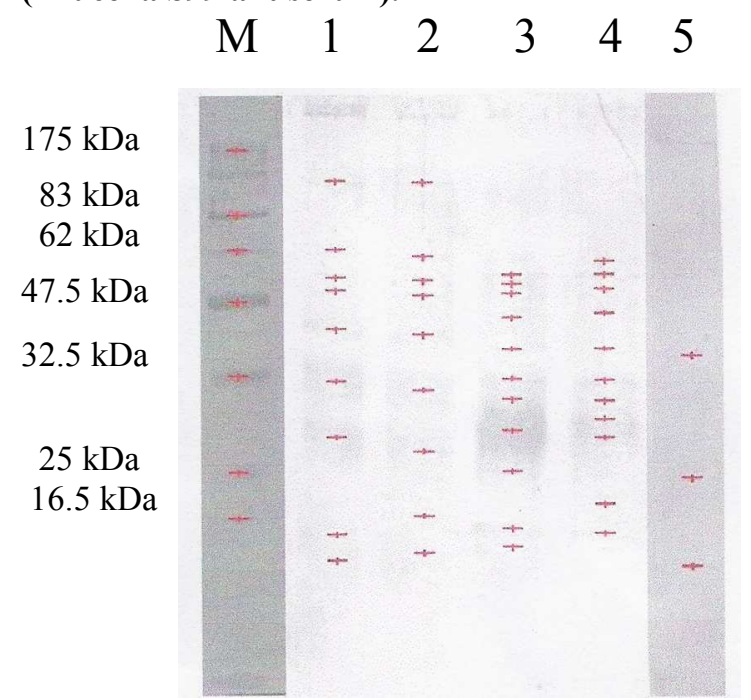

$\mathrm{M}=$ broad range biolab pre-stained marker, Lane (1): untreated Brucella, Lane(2): Brucella treated with $0.02 \mathrm{M}$ of BEI, Lane(3): Brucella treated with $0.03 \mathrm{M}$ of BEI, Lane(4): Brucella treated with $0.04 \mathrm{M}$ of BEI, Lane(5): Heat killed Brucella

agglutination test (RSAT), standard tube agglutination test (SAT), 2- mercaptoetanol tube agglutination test (2ME), complement fixation (CF) test and enzyme-linked immunosorbent assay (ELISA). One major problem in sero diagnosis is the cross reactions that occur between brucellae and other bacteria. A second problem is that a diagnosis of brucellosis cannot be established on the antibody titer alone.

This article describes production and characterization of Brucella abortus S (99) surface antigens. These antigenic structures may be employed in serodiagnostic tests which currently utilize the whole cells bacteria, and consequently it may increase the specificity and decrease cross-reactions between B. abortus and the other bacteria.

The prepared phenol-heat killed bacteria was compared with S 99 inactivated with binary ethylene imine (BEI) in different concentrations ( $0.2 \mathrm{M}, 0.3 \mathrm{M}$ and $0.4 \mathrm{M}$ ). BEI inactivated brucella cells over a period of 3 days at $37^{\circ} \mathrm{C}$, and the viable count was determined periodically till complete inactivation. $0.04 \mathrm{M}, 0.03 \mathrm{M}$ and $0.02 \mathrm{M}$ concentration of BEI inactivated brucella living cells ( 9 X $\left.10^{9} \mathrm{CFU}\right)$ after one day, 2 days and 3 days respectively as shown in Fig (1).

The produced antigens $(0.02 \mathrm{M}, 0.03 \mathrm{M}$ and $0.04 \mathrm{M}$ BEI) were standardized using standard antisera in comparison with the commercial antigen, the Rose Bengal plate test was applied (Alton et al., 1988). Binary inactivated antigen $(0.02 \mathrm{M})$ gave the best results as follows: coarse clumbing, definite cleaning in less than 1 minute with the control $(+++)$ positive antisera. Fine agglutination, definite rim with the control $(++)$ positive antisera. Little agglutination, some rim with the control $(+)$ positive antisera. No agglutination, no rim formation with the control (-) negative antisera

The produced antigen $(0.02 \mathrm{M} \quad \mathrm{BEI})$ was compared with standard Rose Bengal by testing experimentally infected guinea pigs with Brucella abortus 2308 and Brucella melitensis M 16 (virulent stains). All animals were tested for the antibody response of experimentally infected guinea pigs by Rose Bengal test, over a period of 3 months post infection (PI). The antibody response appeared at 10 days post infection (PI), gradually increased till 7 weeks PI then declined gradually till 14 weeks PI.

Using a Bayesian approach, test sensitivity and specificity were estimated and compared as mentioned by Ronald, (1991), no significant differences were detected in sensitivity among various antigens used. However, binary inactivated antigen showed better specificity, and detected guinea pigs infected with Brucella melitensis, as shown in Table (1).

Enzyme immunotransfer blot (EITB) was applied to analyse the antigenic structure of the different antigens. Lane 1 ( untreated Brucella cell ) showed 9 protein bands ranging from $128.355 \mathrm{kDa}$ to $7.83 \mathrm{kDa}$, lane 2 (Brucella cells treated with $0.2 \mathrm{M}$ binary ) showed 9 protein bands ranging from 128.355 to $10.38 \mathrm{kDa}$, lane 3 (Brucella cells treated with $0.3 \mathrm{M}$ binary ) gave 11 protein bands ranging from 54.577 to 10.38 $\mathrm{kDa}$, lane 4 (Brucella cells treated with $0.4 \mathrm{M}$ binary ) gave 11 protein bands ranging from 60.286 to $13.723 \mathrm{kDa}$, and lane 5 ( heat-killed Brucella) showed only 3 bands ranging from 37.375 to $7.83 \mathrm{kDa}$. as shown in Table (2) and Fig (2). These results revealed similarities between lanes $1 \& 2$ i.e. binary ethylene amine $(0.2 \mathrm{M})$ did not show bad affect on living brucella cells during inactivation, while differed slightly from lanes $3 \& 4$. These results agreed with Hassanien, (1992) who recorded that binary ethylene imine inactivated AHV virus (virulent type-9 strain) without detection of residual virus. A concentration of $0.03 \mathrm{M}$ of the inactivating agent is recommended where no changes in viral antigenic properties were noticed in complement 
fixation test. On the other hand phenol-heat killed brucella cells showed only 3 bands, this denotes denaturation for at least 6 bands. This result agreed with Hansel et al. (1994) who recoded that proteins travel as a $140 \mathrm{kDa}$ complex if subjected to SDS-PAGE without heat denaturation, but they collapse into $50 \mathrm{kDa}$ monomers if heated in SDS. Farshad et al., (2002) mentioned that the major B. abortus outer membrane proteins (OMP) have the molecular masses of 36-38 and 25-27 kDa. They are also called group 2 porin proteins and group 3 proteins respectively. Cell wall of $B$. melitensis contains another major protein of molecular mass $31-34 \mathrm{kDa}$, which is minor in $B$. abortus strains. A lipoprotein covalently linked to PG has also been described as a major OMP. Other OMP identified so far are minor species with molecular masses of 10, 16.5, 19 and $89 \mathrm{kDa}$. OMP 10, 16 and 19 share antigenic determinants with bacteria of the family Rizobiaceae. The 89 $\mathrm{kDa}$ OMP is probably a protein of group 1 with a molecular mass of 88-94 $\mathrm{kDa}$ which agreed with the results obtained in the current study. In conclusion, the best method for preparation of Brucella antigen is by adding $0.02 \mathrm{M}$ BEI, because it gave nearly the same result of nontreated Brucella abortus (S 99) with hyperimmune sera prepared from crude Brucella antigen as shown in Fig (2) and Table (2).

\section{References}

Alton, G. G.; Jones, L. M.; Angus, R. D. and Verger, J.M.(1988): Techniques for Brucellosis Laboratory. Inst. Nat. Rech., Argnon, Paris.

Blasco, J. M.; Garin-Bastuji, B.; Marín, C.; Gerbier, G.; Fanlo, J.; Jiménez De Bagués M.; Cau, C. (1994): Efficacy of different Rose Bengal and Complement Fixation antigens for the diagnosis of Brucella melitensis in sheep and goats, Vet. Rec., 134: 415-420.

European Commission (1999): The modification of Technical Annexes of Council Directive 64/432/EEC to take account of Scientific Developments regarding Tuberculosis, Brucellosis and Enzootic Bovine Leucosis.
Report of the Scientific Committee on Animal Health and Animal Welfare adopted 11 October 1999. Sanco/B3/R10/1999. Cited in Manual of Diagnostic Tests and Vaccines for Terrestrial Animals; BOVINE BRUCELLOSIS 2004.

Farshad S.; Mehrabanpour, M. J.; Namavari, M. M.; Hosseini, S M.S.; Tavakkoli, A. and Ghaderi. A.(2002): Iran. Biomed. J., 6 (1): 7-12.

Garin-Bastuji, B.; Blasco, J. M.; Grayon, M. (1998): Brucella melitensis infection in sheep: present and future, Vet.Res., 29: 255-274.

Girard,House,Peter,E.Mikiciok and Mary,Lou Beringer (1990): Laboratory diagnosis of A.H.S. J. Vet. Diag. Inves., 2:44-50.

Hansel, A.; Schmid, A.; Tadras, M. H. and Juergens, U. J. (1994): Isolation and characterization of protein from the outer membrane of Synechococcus PCC 6301, Arch. Microbiol., 161: 163-167.

Hassanien, M. M. (1992): Preliminary findings for an inactivated A.H.V. vaccine using binary ethylene imene. Review Ėlv.Méd.Vét.Payes Trop., 45 (3-4): 231-234.

Joint FAO/WHO (1986): Joint FAO/WHO Expert Commitie on Brucellosis, Sixth Report, Technical Report Series 740, WHO, Geneva, Switzerland, 1986.

Laemmli, U. K. (1970): Cleavage of structural proteins during the assembly of the head Bacteriophage T4. Nature, 227: 680-685.

Moriyon I. and Gamazo C. (1998): Structures and properties of the outer membrane of Brucella abortus and Brucella melitensis, Intern. Microbiol. 1: 19-26.

Nielsen K. (2002): Diagnosis of brucellosis by serology. Vet. Microbiol., 90: 447-459.

Nöckler, S. A.; Scholz, S. C.; Tomaso, H.; Bogumil, R. and Neubauer, $H$ (2006): Immunoproteomic characterization of Brucella abortus 1119-3 preparations used for the serodiagnosis of Brucella infections. J. Immunol. Meth., 309 (1-2): 34-47.

Ronald, D. S. (1991): "Veterinary Clinical epidemiology problem - oriented approach" Butterworth- Heineman, a devision of Reed publ.(USA) Inc.

Sangari F. J. and Aguëro J. (1996): Molecular basis of Brucella pathogenicity: an update, Microbiología SEM, 12 :207-218.

Schurig G.G., Sriranganathan N. and Corbel M.J. (2002): Brucellosis vaccines: past, present and future, Vet. Microbiol., 90: 479-496.

World Health Organization (1997): WHO Guidelines for the Safe Transport of Infectious Substances and Diagnostic Specimens, WHO, Geneva, Switzerland, WHO/EMC/97.3. who.int/emc/biosafety.html

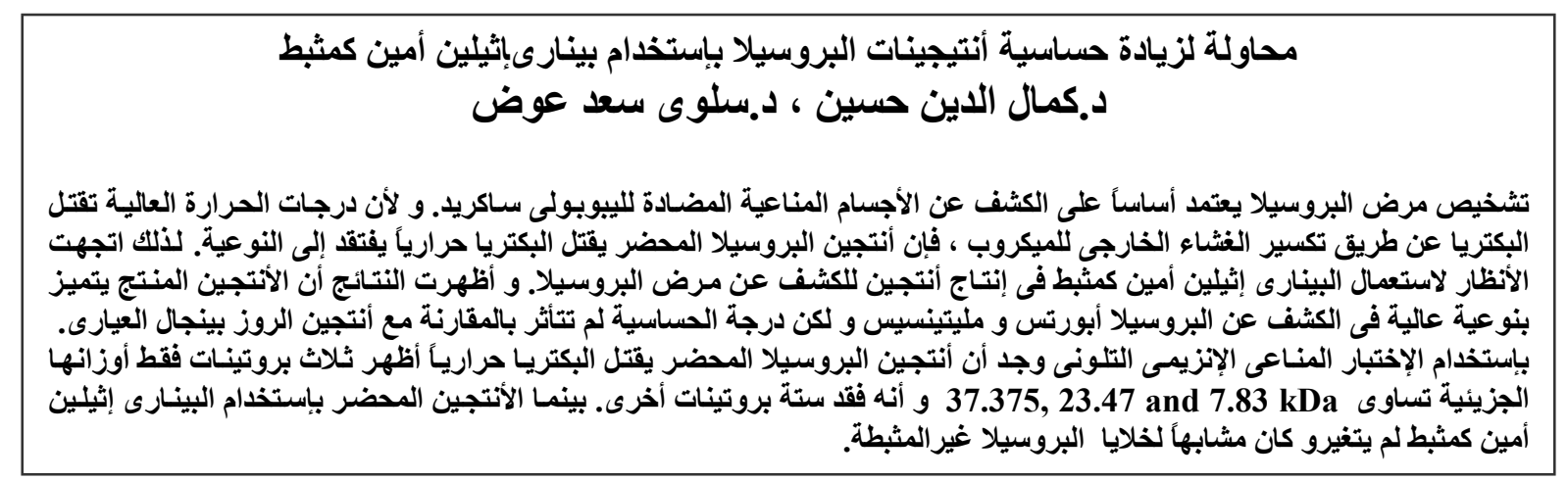

